\title{
Impact of using a lymph node revealing solution in surgical specimens for pathological staging of gastric cancer
}

\author{
Uso de solução reveladora de linfonodos em peças cirúrgicas, no estadiamento \\ anatomopatológico do câncer gástrico
}

Márcio Tadeu Diniz de Sousa ${ }^{1}$; Paulo Roberto Savassi-Rocha²; Mônica Maria Demas Álvares Cabral ${ }^{3}$

\begin{abstract}
Introduction: Lymph node (LN) metastasis is a major staging criterion of gastric cancer (GC). GC prognosis is associated with the number of metastatic LNs. Objective: To evaluate the impact of using a lymph node revealing solution (LRS) in gastrectomy specimens. Material and methods: prospective study in 30 gastrectomy specimens (19 men, average age of 59.5; 11 women, average age of 66.1) for pathological tumor, node, metastasis (TNM) staging. After LN dissection according to the routine procedures (conventional method [CM]), the tissue was emerged in LRS: a mixture containing 65\% ethanol, 20\% ether, $5 \%$ acetic acid, and 10\% formalin solution (10\%), for 36 hours with 3 changes. A new LN dissection was performed. The number of LNs obtained from both methods was compared and analyzed. The number of metastatic and non-metastatic LNs was determined. Results: From 1,005 (33.5/specimen) dissected LNs, 657 of which (21.9/specimen) by the CM, and 348 (11.6/specimen) after using LRS $(\phi=0.0002)$, metastases were detected in 272 LNs (9.2/case), 211 of which (7.0/specimen) were found with the CM, and 61 (2.0/specimen) after using LRS ( $\phi=0.0028)$. The number of LNs increased $53.0 \%$ with LRS, and the number of metastatic LNs was $28.9 \%$ higher. The $\mathrm{pN}$ classification changed in 5 (16.7\%) of the 30 specimens, and in stage grouping in $4(13.3 \%)$ analyzed cases. Conclusion: The use of LRS in gastrectomy specimens is simple, enables dissection, increases the number of LNs, and occasionally changes $\mathrm{pN}$ staging and stage grouping.
\end{abstract}

Key words: gastric cancer; lymph nodes; dissection; lymph node revealing solution.

\section{INTRODUCTION}

Gastric cancer (GC) is the second leading cause of deaths due to cancer and the fourth most common cancer worldwide ${ }^{(9)}$. The disease occurs twice as often in men as in women in almost all countries ${ }^{(10)}$.

The GC mortality/incidence ratio is considerably high worldwide, and the five-year survival rate is low, around $20 \%$ in most developing countries ${ }^{(23)}$.

Worldwide, 989,600 new cases and 738,000 deaths are estimated per year, although incidence and mortality have decreased over the past 50 years in many regions. This decrease in many developed countries has been attributed to changing dietary habits, food preservation, and control of Helicobacter pylori infection ${ }^{(23)}$.
GC prognosis is mainly based on staging and is related to the depth of tumor invasion and the presence of lymph node (LN) metastasis. These characteristics, combined with other pathological aspects, define the course of treatment. Therefore, the surgical approach with curing purposes, involving gastrectomy and lymphadenectomy, is considered the only intervention able to prolong survival.

The tumor-node-metastasis (TNM) system for GC classification is widely used, providing prognostic information, especially with regard to $\mathrm{LN}$ involvement, which is one of the most important criteria used for GC staging. There is a relationship between GC prognosis and the number of LNs affected by metastasis ${ }^{(5)}$.

Numerous studies have shown benefits of radical lymphadenectomy in relation to survival and the potential of

First submission on 18/03/14; last submission on 22/09/14; accepted for publication on 16/10/14; published on 20/12/14

1. MsC Applied to Surgery and Ophthalmology, concentration area Surgical Anatomic Physiopathology, Post-Graduation Program at Minas Gerais Federal University (UFMG).

2. PhD in Surgery by UFMG; head of Instituto Alfa de Gastroenterologia of Hospital das Clínicas-UFMG.

3. PhD in Pathology by UFMG; assistant professor at Department of Anatomic Pathology and Pathological Medicine-UFMG. 
cure ${ }^{(8,12,28,34)}$. Therefore, a meticulous dissection of LNs is one of the most important factors in macroscopic evaluation of specimen resulting from radical surgical treatment for $\mathrm{GC}$.

Detection and analysis of the highest possible number of LNs are essential for correct classification, therapeutic decision making, and GC prognosis. However, these prerogatives frequently fall short of what is desirable, not only for issues inherent to the patient (obesity, for example, which makes it difficult to obtain the LN from the surgical specimen), but also to the surgeon (surgical technique), and to the pathologist (quality of anatomopathological examination).

Lymph Node Revealing Solutions (LRS) contain 65\% of commercial 95\% ethyl alcohol, 20\% diethyl ether, 5\% glacial acetic and $10 \%$ of $10 \%$ formalin, chemicals that clarify the fat of surgical specimens immersed in them for a determined period of time, showing the LNs, which become chalky. LRS has been used in surgical specimens of colon and rectum, ${ }^{(4,19)}$, breast and axilla ${ }^{(7)}$ in order to enable LNs identification in these specimens, ensuring that as many LNs as possible are evaluated on macroscopic and microscopic aspects.

\section{MATERIAL AND METHODS}

A prospective study of a consecutive series of 30 gastrectomy specimens was conducted (19 men, mean age of 59.5, and 11 women, mean age of 66.1). Among the 30 gastrectomy specimens, 13 (43.3\%) were total gastrectomy with $\mathrm{D} 2$ dissection; one (3.3\%), total gastrectomy D1; two (6.7\%), subtotal gastrectomy D1; nine (30\%), subtotal gastrectomy D2; four (13.3\%), subtotal gastrectomy with no classification of the type of LN dissection; and one (3.3\%) with no classification of the type of gastrectomy.

Most tumors were carcinomas ( $n=26 ; 87 \%)$, among which five cases (19.2\%) were diffuse-type, seven (26.9\%) were mixed-type, and 14 (53.8\%), intestinal-type (Laurén's histological classification) ${ }^{(17)}$. One case (3\%) was not classified and three $(10 \%)$ were undefined.

The study was approved by the Research Ethics Committee (COEP) of Universidade Federal de Minas Gerais (UFMG) - Project CAAE - 0090.0.203.000-11, and held in the Gastrointestinal Pathology Service of the Department of Pathological Anatomy and Forensic Medicine (APM) (Departamento de Anatomia Patológica e Medicina Legal do Hospital das Clínicas da UFMG).

A transversal prospective study was carried out in 30 samples of total and subtotal gastrectomy specimens with D1 and D2 LN dissections, derived from surgical treatment of patients chosen randomly, GC carriers, from Instituto Alfa de Gastroenterologia do Hospital das Clínicas-UFMG, Belo Horizonte, Minas Gerais, from December 2010 to January 2012.

All samples were processed and analyzed at the APM, according to the anatomopathologic $\operatorname{protocol}^{(18)}$, which comprises macroscopic and microscopic evaluation of the tumor, including tumor measures, macroscopic Borrmann type $e^{(2)}$, location, histological type according to Laurén's classification $^{(17)}$ and the World Health Organization (WHO) ${ }^{(35)}$, growth pattern described by Ming ${ }^{(22)}$, presence of lymphatic vascular invasion (LVI), blood vascular invasion (BVI), and anatomopathological TNM staging(5).

The patients' records, such as age, gender, registration number, type of surgery, tumor nature and site, neoadjuvant radiotherapy and chemotherapy, were obtained from the laboratory orders. Information on macroscopic and microscopic examination of the tumor was collected from the anatomopathological reports. We assessed only the characteristics of the tumor $(\mathrm{T})$ and lymph node $(\mathrm{N})$ involvement according to TNM staging.

All samples taken from gastrectomy specimens for histopathological study, according to the APM's cleavage map protocol (Figure 1), were previously fixed in 10\% formalin and processed in the APM, embedded in paraffin blocks.

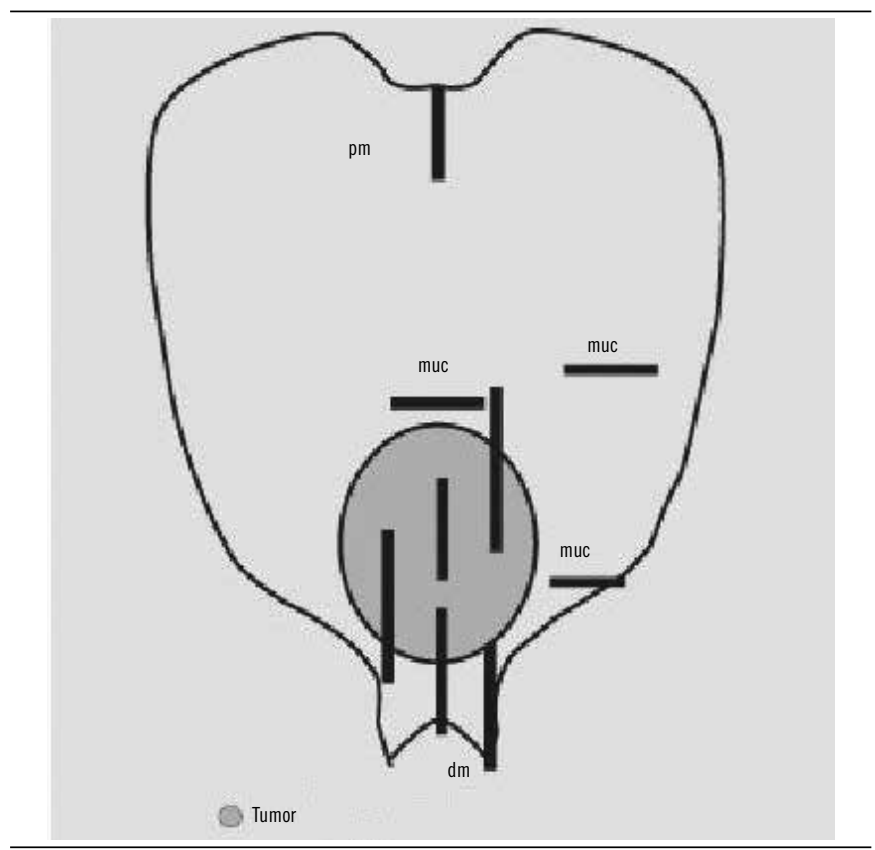

FIGURE 1 - Cleavage map for GC surgical specimens processing: sample for histological analysis ${ }^{(18)}$

GC: gastric cancer; pm: proximal margin; dm: distal margin; muc: mucosa. 
Significant samples of tumor, of adjacent mucosa (three to six pieces), of the proximal and distal margins of surgical resection, matching with the greater and lesser curvatures, of the gastric mucosa of the antrum, the body and the angular notch, as well as all dissected LNs, were subjected to histological examination. The slides were stained with hematoxylin-eosin (HE) for histological diagnosis. The perigastric tissue remaining after the LNs dissection by the conventional method (CM), which would be disposed of with the surgical specimen, was immersed in LRS, in three baths, with the duration of 12 hours each, and, after 36 hours, the LNs stand out as chalky nodules amid a yellowish tissue. We performed a new dissection of LNs, now under direct vision. They were then subjected to histopathological study.

After histopathological examination of the new dissected LNs, the cases were staged concerning $\mathrm{pN}$, according to the total number of dissected LNs (the number of LNs dissected by CM, plus the number of LNs dissected after using LRS).

We did not include cases of patients with benign gastric tumors, carcinoid tumors, lymphomas, stromal-derived tumors, sarcomas, and those undergoing neoadjuvant radiotherapy and/or chemotherapy.

\section{Statistical analysis}

The data collected were entered into a database developed in Excel $^{\circledR}$. The analyses were performed in R and Epi Info ${ }^{\mathrm{TM}}$ softwares. We used a significance level of $5 \%(\phi \leq 0.05)$.

Quantitative variables of interest were the total number of LNs and the number of LNs with metastases, before and after using LRS. The categorical variable of interest was the change in TNM classification after using LRS.

Comparisons between quantitative and categorical characteristics (binary) were performed by Student $t$-test and Mann-Whitney test. In cases in which categorical characteristic showed more than two categories, F-test (ANOVA) and Kruskal-Wallis test were used. The supposition of normality was checked by the Shapiro-Wilk test.

In order to compare the two characteristics in categorical form, we applied chi-square test incorporating Yates' correction for comparison of proportions, when there were only two categories in each variable. In cases with more than two categories, we used Pearson's chi-squared test. In the presence of at least one expected frequency lower than five, we used Fisher's exact test.

Among the quantitative characteristics, we calculated the Pearson's correlation coefficient and Spearman's correlation coefficient.

\section{RESULTS}

\section{Lymph nodes}

We dissected a total of 1,005 LNs, mean of $33.5 \mathrm{LNs} / \mathrm{case}$ \pm 21.5 LNs. The number of metastatic LNs was 272 , mean of $9.1 \mathrm{LNs} /$ case $\pm 17.4 \mathrm{LNs}$; and non-metastatic LNs, 733, mean of 24.2 LNs/case $\pm 18.4 \mathrm{LNs}$. Before exposure to LRS, $657 \mathrm{LNs}$ were dissected, mean of $21.9 \mathrm{LNs} / \mathrm{case} \pm 15.6 \mathrm{LNs}$. The number of metastatic LNs before exposure to LRS was 211, mean of $7 \mathrm{LNs} /$ case $\pm 12.8 \mathrm{LNs}$; and non-metastatic LNs, 446 , mean of $14.9 \mathrm{LNs} /$ case $\pm 12.7 \mathrm{LNs}$. The number of LNs dissected after LRS exposure was 348, mean of $11.6 \mathrm{LNs} / \mathrm{case} \pm 8.9 \mathrm{LNs}$; and non-metastatic LNs, 61, mean of $2 \mathrm{LNs} / \mathrm{case} \pm 4.9 \mathrm{LNs}$; and non-metastatic LNs, 287, mean of $9.6 \mathrm{LNs} /$ case $\pm 8.4 \mathrm{LNs}$ (Table 1).

TABLE 1 - Number of lymph nodes (metastatic and non-metastatic) before and after exposure to LRS

\begin{tabular}{cccc}
\hline Total of lymph nodes & $n$ & Mean & SD \\
\hline Total & 1005 & 33.5 & 21.5 \\
Metastatic & 272 & 9.1 & 17.4 \\
Non-metastatic & 733 & 24.2 & 18.4 \\
\hline Before LRS & 657 & 21.9 & 15.6 \\
Metastatic & 211 & 7 & 12.8 \\
Non-metastatic & 446 & 14.9 & 12.7 \\
\hline Additional after LRS & 348 & 11.6 & 8.9 \\
Metastatic & 61 & 2 & 4.9 \\
Non-metastatic & 287 & 9.6 & 8.4 \\
\hline
\end{tabular}

LRS: lymph node revealing solution; $n$ : number of observation; SD: standard deviation. Source: SOUSA, M. T. D. et al. (2014) ${ }^{(32)}$.

\section{Impact of using LRS}

\section{Number of lymph node}

After using LRS, we identified 348 more LNs, which represent $53 \%$ of the amount identified before LRS $(p=0.0002)$.

The number of metastatic LNs increased from 211 to 272, after using LRS, thus, increasing 28.9\% ( $p=0.0028)$ (Figure 2).

There was a positive correlation between the average number of LNs and the average number of metastatic LNs found before and after LRS immersion $(\phi<0.05)$ (Table 2). It should be stressed that the values shown in the column "After" represent the total of LNs after immersion in the solution, and not only the new LNs identified. 


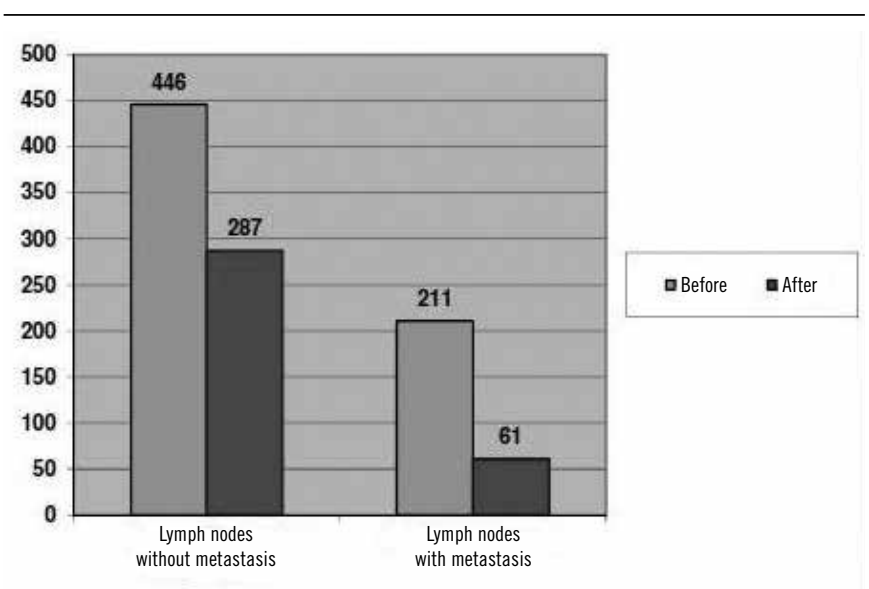

FIGURE 2 - Number of metastatic and non-metastatic lymph nodes before and after LRS LRS: lymph node revealing solution.

TABLE 2 - Average number of lymph nodes and metastatic lymph nodes before and after LRS immersion

\begin{tabular}{|c|c|c|c|c|c|c|c|}
\hline \multirow{3}{*}{ Characteristic } & \multicolumn{6}{|c|}{ Time } & \multirow{3}{*}{$p$ value } \\
\hline & \multicolumn{3}{|c|}{ Before } & \multicolumn{3}{|c|}{ After } & \\
\hline & Mean & SD & Median & Mean & $\mathrm{SD}$ & Median & \\
\hline $\begin{array}{c}n \text { total } \\
\text { lymph nodes }\end{array}$ & 21.9 & 15.6 & 16.5 & 33.5 & 21.5 & 29 & $<0.001^{1}$ \\
\hline $\begin{array}{l}n \text { metastatic } \\
\text { lymph nodes }\end{array}$ & 7 & 12.8 & 2 & 9.1 & 17.4 & 3 & $0.002^{2}$ \\
\hline
\end{tabular}

1: paired t-test; 2: Wilcoxon test.

LRS: lymph node revealing solution; SD: standard deviation.

Source: SOUSA, M. T. D. et al. (2014) (32).

\section{Staging}

After using LRS, five (16.7\%) from the 30 cases have changed $\mathrm{pN}$ status. Two cases (22.2\%) initially pN1 were restaged pN2; two cases (33.3\%) initially pN2 were restaged pN3; and the case pNX was restaged $\mathrm{pN} 0$.

From these five cases, four (80.0\%) changed the stage grouping, which represents $13.3 \%$ of the total sample. Two cases staged IIB before using LRS were restaged IIIA; two cases staged IIIA were restaged IIIB (Table 3).

TABLE 3 - Change in $\mathrm{pN}$ and staging classification

\begin{tabular}{ccc}
\hline Case & Before LRS & After LRS \\
\hline 1107235 & $\mathrm{pN} 1-$ IIB & $\mathrm{pN} 2-$ IIIA \\
1104890 & $\mathrm{pN} 2-$ IIIA & $\mathrm{pN3a}-$ IIIB \\
1103494 & $\mathrm{pN} 2-$ IIIA & $\mathrm{pN3a}-$ IIIB \\
1105741 & $\mathrm{pN} 1-$ IIB & $\mathrm{pN} 2-$ IIIA \\
\hline
\end{tabular}

LRS: lymph node revealing solution; $p N$ : lymph node pathologic in Tumor-NodeMetastasis system.

\section{DISCUSSION}

GC is a disease with high prevalence and high incidence almost worldwide, and has been studied with the purpose of promoting a better understanding of its pathogenesis, prevention, treatment and prognosis. GC should be treated by gastrectomy with regional lymphadenectomy.

Studies have shown that the survival of patients with GC is related, among other factors, to the number of regional $\mathrm{LN}$ metastasis. The potential of identifying the affected LNs increases with the number of dissected and studied LNs.

The proportion of $\mathrm{N}$ advanced status increases with the number of LNs examined, and its relation to patients' survival is probably affected by migration of tumors staging ${ }^{(12)}$.

There are reports in the literature of studies using LRS in surgical specimens of breast, colon and rectum, intended to facilitate the visualization and dissection of LNs. Studies involving GC gastrectomy specimens are rare, and this fact motivated our research. The number of affected LNs is one of the most important prognostic indicators for GC. In patients with comparable T-category, the greater the number of affected LNs removed, the better survival they will have ${ }^{(8)}$.

It is generally accepted that there is greater benefit in survival from LNs standardized dissections ${ }^{(11)}$. Many studies have shown that the number of LNs dissected is closely related to postoperative pathological tumor staging and prognostic assessment. A sufficient number of dissected LNs improves the reliability of staging and provides a more accurate prognostic evaluation ${ }^{(1,3)}$. Despite the importance of the need for accurate staging, recent studies suggest that the assessment for LNs staging in GC is inadequate in 62\% to 71\% of patients. Insufficient assessment of LNs has potentially important implications for the appropriate adjuvant therapy, and affects the comparisons between studies on the different treatments for $\mathrm{GC}^{(27)}$.

The LN status is the most important prognostic criterion to predict recurrence and survival in patients with GC without evidence of metastases. The American Joint Committee on Cancer and the International Union Against Cancer (AJCC/UICC) take into account the total number of LN-positive for metastasis and not the total number of $\mathrm{LN}$ or the $\mathrm{LN}$ positive/negative ratio for cancer staging. Studies suggest that survival is highly dependent on the number of post-gastrectomy affected LNs ${ }^{(31)}$.

Tumors are understaged by reasons concerning the surgical team, as, when removing little tissue, they may leave LNs in the surgical site; and also concerning the pathologist, who is required to know the technique, to have the skills and to be attentive during 
dissection and microscopic examination of $\mathrm{LNS}^{(24)}$. The research method for LNs gastrectomy specimen, mentioned in this work as CM, is based on visualization and haptic perception of LNs through thin-sections of perigastric tissue. This method is very time consuming and often ineffective in showing all LNs present in the specimen, and may not detect LNs of five millimeters in size or less, which can harbor metastatic disease in up to $33 \%$ of cases $^{(4)}$.

LRS use in surgical specimens can double or even triple the number of dissected LNs when compared with the CM. SchmitzMoormann $e t$ al.${ }^{(26)}$ suggested that a review of the number of LNs examined and involved by the tumor, in addition to other evaluations, brings satisfactory results by using techniques that reveal LNs.

In the present study, we used the LRS described by Koren et $a l{ }^{(13)}$, aiming to evaluate the number of additional LNs after its use in gastrectomy specimens, as well as the impact of the result in GC anatomopathological staging. In this study, in one case it was not possible to describe the type of gastrectomy performed, and the four cases in which the types of LN dissections were not described were included in the study because they would not have influence in counting the number of LNs, and therefore on the study's purpose.

Luebke et al. ${ }^{(20)}$ used the same LRS in 11 cases, achieving 452 LNs by CM (average of $41.1 \mathrm{LNs} / \mathrm{case}$ ) and 138 LNs (average of $12.5 \mathrm{LNs} / \mathrm{case}$ ) after using LRS (increase of 30.5\%), with no change in pN status in any case.

Koren et $a l^{(13)}$ used it in 10 gastrectomy specimens. By CM, the authors found $30 \mathrm{LNs}$ with an average size of $6.69 \mathrm{~mm} \pm 3.43 \mathrm{~mm}$. Using LRS they obtained 89 additional LNs (increase of 296.7\%), with an average size of $3.03 \mathrm{~mm} \pm 3.43 \mathrm{~mm}$. The $\mathrm{pN}$ staging changed in four cases from $\mathrm{pNX}$ to $\mathrm{pN} 0$, in one case from $\mathrm{pN} 1$ to $\mathrm{pN} 2$, and in one case from $\mathrm{pN} 0$ to $\mathrm{pN} 2$.

In Brazil, a study conducted by the Grupo de Estômago e Duodeno do Departamento de Cirurgia e Departamento de Ciências Patológicas da Faculdade de Ciências Médicas da Santa Casa de São Paulo used LRS in 13 gastrectomy pieces, finding 222 LNs by CM (mean of $17.07 \mathrm{LNs} / \mathrm{case}$ ) and, after using LRS, they found 123 more LNs (mean of $9.46 \mathrm{LNs} / \mathrm{case}$ ) ${ }^{(29)}$, an increase of $55.5 \%$.

In this study, the mean of LNs dissected by CM was 21.9 $\pm 15.6 \mathrm{LN}$, similar to some studies described in the literature (Table 4).

After using LRS, 348 additional LNs were dissected, representing an increase of $53 \%(\phi=0.00002)$. The discrepancy in the increase in the number of LNs found by Koren $e t a l{ }^{(13)}$ in

\begin{tabular}{cc}
$\begin{array}{c}\text { TABLE 4 - Average number of lymph nodes obtained by conventional } \\
\text { method in different series of gastric cancer }\end{array}$ \\
\hline Series & LNs/case \\
\hline Present series $(2014)^{(32)}$ & 21.9 \\
DAZI, X. et al. $(2012)^{(33)}$ & 23.5 \\
MEDINA-FRANCO, H. et al. $(2013)^{(21)}$ & 18 \\
BIFFI, R. et al. $(2011)^{(1)}$ & 22 \\
DIKKEN, J. L. et al. $(2012)^{(6)}$ & 23 \\
KWON, H. Y. et al. $(2013)^{(15)}$ & 31.6
\end{tabular}

relation to this and other studies may result from the study of 10 cases, in which a total of 30 LNs were dissected, therefore a mean of three LNs/case is very low on the basis of the studies described above, but the LNs were very large. After using LRS, 89 LNs were found in very small sizes, thus considerably increasing the total number of LNs.

Sun Z. et al. ${ }^{(33)}$ retrospectively studied 2,159 patients who had undergone gastrectomy with curing purposes for $\mathrm{GC}$, observing a linear correlation between the number of acquired LNs and the number of metastatic LNs.

Studies conducted by Luebke et al. ${ }^{(20)}$, Koren et al.$^{(13)}$, Candela et $a l{ }^{(4)}$ do not mention the percentage rate of increase in the number of metastatic LNs after using LRS. Siqueira et al. ${ }^{(29)}$ had an increase of $20.5 \%$ in metastatic LNs using LRS.

In this study, after using LRS, the increase in the number of dissected LNs resulted in the increase (28.9\%) of metastatic LNs found $(p=0.0028)$, changing the $\mathrm{pN}$ staging in five cases $(16.7 \%)$. In one of them, no LN was found using CM and, after using LRS in the gastrectomy specimen, 10 LNs were dissected, all non-metastatic, allowing $\mathrm{pNX}$ restaging to $\mathrm{pN} 0$. There was a change in stage grouping in four cases (13.3\%). Luebke et al. ${ }^{(20)}$ and Siqueira $e t a l{ }^{(29)}$ did not observe changes in $\mathrm{pN}$ staging, but the number of cases in their study was small. Koren et al. ${ }^{(13)}$ observed a change in $\mathrm{pN}$ staging in six out of 10 cases studied $(60 \%)$, however, the average of LNs achieved (three LNs/case) was very low by CM, increasing considerably after using LRS, probably explaining the $\mathrm{pN}$ change. In two cases of this study, we did not achieve the minimum number of 16 LNs by CM, and they were not affected by metastases. After immersion of the pieces in LRS, the new dissection enabled us to achieve the minimum number of 16 LNs. AJCC/UICC ${ }^{(5)}$ suggest that at least 16 regional LNs should be identified in the surgical specimen for pN0 to be determined. In both mentioned cases, we were in doubt whether patients were understaged due to failing to have 16 LNs analyzed. After using LRS, the number of 16 LNs was achieved in one case, and 19 LNs in the other, enabling a more secure staging, despite the fact that the 
pN classification did not change. Several studies described in the literature concluded that there must be 16 or more LNs analyzed for pN0 staging to be achieved $^{(1,16,21,27,31)}$. Son et al. ${ }^{(31)}$ analyzed the survival rate of 10,010 patients and concluded that when 15 or less LNs are examined and findings show no metastases (classified pN0 by TNM system), it is not possible to appropriately predict the survival of patients undergoing curative gastrectomy. In one case of this study, we did not find LNs using CM, and after using LRS in the gastrectomy specimen we dissected $10 \mathrm{LNs}$, all non-metastatic, allowing restaging $\mathrm{pNX}$ to $\mathrm{pN} 0$.

The total number of dissected LNs, i.e., those achieved by CM and after using LRS, was 1,005, with an average of $33.5 \mathrm{LNs} /$ case. This number is above the average of LNs mentioned by most authors included in Table 4.

\section{CONCLUSION}

Regarding the use of LRS in GC gastrectomy specimens, it is possible to conclude that it provides a significant increase in the number of metastatic and non-metastatic LNs when compared to CM, occasionally involving changes in $\mathrm{pN}$ staging and stage grouping. The technique makes the dissection process easier and improves the results, in addition to being simple and low cost. Thus, it should be recommended.

\section{RESUMO}

Introdução: O envolvimento do linfonodo (LNs) por metástase é importante critério para estadiar câncer gástrico (CG). Relaciona-se o prognóstico do CG com número de LNs metastáticos. Objetivo: Avaliar o impacto do uso de solução reveladora de linfonodos (SRL) em espécimes de gastrectomia. Material e métodos: Estudo prospectivo em 30 espécimes de gastrectomia (19 homens, média de idade 59,5 anos, e 11 mulheres, média de idade 66,1 anos) para estadiamento patológico tumor-linfonodo-metástase (TNM). Após dissecção dos LNs de acordo com procedimento de rotina (método convencional [MC]), esse tecido foi imerso em SRL, mistura contendo 65\% de álcool, 20\% de éter, 5\% de ácido acético e 10\% de formal a 10\%, por 36 horas, com três mudanças, sendo realizada nova dissecção de LNs. Os LNs obtidos por ambos os métodos foram comparados e analisados. O número de LNs metastáticos e sem metástases foram determinados. Resultados: Dissecados 1.005 LNs (33,5/caso): 657 LNs (21,9/caso) pelo MC e 348 LNs (11,6/caso) após uso da SRL ( $\mathrm{p}=0,0002)$. Metástases foram detectadas em $272 \mathrm{LNs}$ (9,2/caso): 211 (sete/ caso) pelo MC e 61 (dois/caso) após uso de SRL ( $\mathrm{p}=0,0028)$. O uso da SRL aumentou o número de LNs em 53\%, e o número de LNs metastáticos, em 28,9\%. Houve mudança na classificação pN em cinco (16,7\%) dos 30 espécimes, e no estadiamento por grupos em quatro (13,3\%) casos analisados. Conclusão: O uso de SRL em espécimes de gastrectomia éprocedimento simples de aplicar, facilitando a dissecção, aumentando o número de LNs e eventualmente mudando estadiamento pN e de grupamento.

Unitermos: câncer gástrico; linfonodos; dissecção; solução reveladora de linfonodos.

\section{REFERENCES}

1. BIFFI, R. et al. Impact on survival of the number of lymph nodes removed in patients with node-negative gastric cancer submitted to extended lymph node dissection. Eur J Surg Oncol, v. 37, n.4, p. 305-11, 2011.

2. BORMMANN, R. Geschwulste des magens und duodenums. In: HENSKE,F:;LUBARSCHO. (Eds.). Handbuch der speziellen pathologischen anatomie und histologie. Berlin: Springer- Verlag, 1926. p. 865.

3. BOUVIER, A. M. et al. How many nodes must be examined to accurately stage gastric carcinomas? Results from a population based study. Cancer, v. 94, n.11, p. 2862-6, 2002.

4. CANDELA, F. C.; URMARCHER, C.; BRENAN, M. F. Comparison of the conventional method of lymph node staging with a comprehensive fatclearing method for gastric adenocarcinoma. Cancer, v. 66, n. 8, p. 182832, 1990 .
5. COMPTON, C. C. et al. AJCC cancer staging atlas: a companion to the seventh editions of the AJCC cancer stage manual and handbook. Stomach. 2. ed. New York: Springer, 2012. Cap.11; p. 143-55.

6. DIKKEN, J. L. et al. Preoperative chemotherapy does not influence the number of evaluable lymph nodes in resected gastric cancer. Eur J Surg Oncol, v. 38, n. 4, p. 319-25, 2012.

7. DURKIN, K; HAAGENSEN, C. D. An improved technique for the study of lymph nodes in surgical specimens. Ann Surg, v. 192, n. 4, p. 419-29, 1980.

8. HUANG, C. M. et al. Impact of the number of dissected lymph nodes on survival for gastric cancer after distal subtotal gastrectomy. Gastroenterology Research and Practice, v. 2011, 476014, 2011.

9. INCA. Instituto Nacional do Câncer. Estimativa 2012. Incidência de câncer no Brasil. Available at: < http://www.inca.gov.br/estimativa/2012/ index.asp?ID=5>. Access: 5 May 2013. 
10. JEMAL, A. et al. Global cancer statistic. CA Cancer J Clin, v. 61 n. 2, p. 69-90, 2011. Erratum in: CA Cancer J Clin, v. 61, n. 2, p. 134, 2011.

11. KIM, J. P. et al. Clinicopathologic characteristics and prognostic factors in 10,783 patients with gastric cancer. Gastric Cancer, v. 1, n. 2, p. $125-33,1998$.

12. KONG, S. H. et al. Stage migration effect on survival in gastric cancer surgery with extended lymphadenectomy: the reappraisal of positive lymph node ratio as a proper N-staging. Ann Surg, v. 255, n. 1, p. 50-8, 2012.

13. KOREN, R. et al. Lymph node revealing solution: simple new method for detecting minute lymph node in colon carcinoma. Dis Colon Rectum, v. 40, n. 4, p. 407-10, 1997.

14. KOREN, R. et al. Lymph node revealing solution: a new method for lymph node sampling: results in gastric adenocarcinoma. Oncol Rep, v. 5 , p. 341-4, 1998.

15. KWON, H. Y. et al. Outcomes of laparoscopic gastrectomy after endoscopic treatment for gastric cancer: a comparison with open gastrectomy.J Gastric Cancer, v. 13, n. 1, p. 51-7, 2013.

16. KWON, S. J. Evaluation of the $7^{\text {th }}$ UICC TNM Staging System of Gastric Cancer.J Gastric Cancer, v. 11, n. 2, p. 78-85, 2011.

17. LAUREN, P. The two histological main types of gastric carcinoma: diffuse and so-called intestinal-type carcinoma. an attempt at a histoclinical classification. Acta Pathol Microbiol Scand, v. 64, p. 31-49, 1965.

18. LEMES, L. A. O. et al. Carcinoma gástrico: análise sistemática de 289 gastrectomias consecutivas em Belo Horizonte (MG). J Bras Patol Med $L a b$, v. 39, n. 1, p. 57-65, 2003.

19. LINDBOE, C. F. Lymph node harvest in colorectal adenocarcinoma specimens: the impact of improved fixation and examination procedures. APMIS, v. 119, n. 6, p. 347-55, 2011. Review.

20. LUEBKE, T. et al. Lymph node revealing solution in gastric carcinoma does not provide upstaging of the N-status. Oncol Rep, v. 13, n. 2, p. 3615,2005 .

21. MEDINA-FRANCO, H. et al. Lymph node ratio as a predictor of survival in gastric carcinoma. Am Surg, v. 79, n. 3, p. 284-9, 2013.

22. MING, S. C. Gastric carcinoma. A pathobiological classification. Cancer, v. 39, n. 6, p. 2475-85, 1977.

23. NAGINI, S. Carcinoma of the stomach: a review of epidemiology, pathogenesis, molecular genetics and chemoprevention. World $J$ Gastrointest Oncol, v. 4, n. 7 p. 156-69, 2012.
24. PARKASH, V. et al. To count and how to count that is the question: interobserver and intraobserver variability among pathologists in lymph node counting.Am Clin Pathol, v. 134, n. 1, p. 42-9, 2010.

25. SCHMITZ-MOORMANN, P. et al. Patho-anatomical demonstration of lymph node metastases in a surgical specimen. Pathol Res Pract, v. 174, n. 4, p. 403-11, 1982.

26. SCHOENLEBER, S. J. et al. Factors influencing lymph node recovery from operative specimen after gastrectomy for gastric adenocarcinoma. J Gastrointest Surg, v. 13, n. 7, p. 1233-7, 2009.

27. SEEVARATNAM, R. et al. How many lymph nodes should be assessed in patients with gastric cancer? A systematic review. Gastric Cancer, v. 15 , n. 1, p. 70-88, 2012.

28. SIEWERT, J. R. et al. Relevant prognostic factors in gastric cancer: ten-year results of the German Gastric Cancer Study. Ann Surg, v. 228, n. 4, p. 449-6, 1998.

29. SIQUEIRA, P. R. et al. Eficácia da solução reveladora de linfonodos em peças de gastrectomia com linfadenectomia por adenocarcinoma gástrico. Rev Col Bras, v. 27, n. 4, p. 221-6, 2000.

30. SMITH, D. D.; SCHWARZ, R. R.; SCHWARZ, R. E. Impact of lymph node count on stage and survival after gastrectomy for gastric câncer: data from a large US-population database. J Clin Oncol, v. 23, n. 28, p. 7114-24, 2005.

31. SON, T. et al. Clinical implication of an insufficient number of examined lymph nodes after curative resection for gastric cancer. Cancer, v. 118, n. 19, p. 4687-93, 2012.

32. SOUSA, M. T. D.; SAVASSI-ROCHA, P. R.; CABRAL, M. M. D. A. Uso de solução reveladora de linfonodos, em peças cirúrgicas, no estadiamento anatomopatológico do câncer gástrico. $2014.72 \mathrm{f}$. Dissertação (Mestrado). Instituto Alfa de Gastroenterologia. Universidade Federal de Minas Gerais, Belo Horizonte. 2014.

33. SUN, Z. et al. The impact of N-ratio in minimizing stage migration phenomenon in gastric cancer patients with insufficient number or level of lymph node retrieved: results from a Chinese mono-institutional study in 2159 patients. Ann Oncol, v. 20, n. 5, p. 897-905, 2009.

34. XU, D. et al. Effect of lymph node number on survival of patients with lymph node-negative gastric cancer according to the $7^{\text {th }}$ edition UICC TNM system. PLoS One, v. 7, n. 6, 2012.

35.WHO classification of tumor of the digestive system. 4. ed. Lyon: IARC Press, 2010. v. 3, p. 417.

\section{MAILING ADDRESS}

Márcio Tadeu Diniz de Sousa

Rua José Gonçalves de Oliveira, 579, apto 302; Jardim Arizona; CEP: 35700-297; Sete Lagoas-MG, Brazil; e-mail: mtds@uai.com.br. 